\title{
Biodiversity of insects and distribution pattern from Sirumallai Hills, Eastern Ghats, Tamil Nadu, South India
}

\begin{abstract}
In the present investigation is an attempt to assess the relative abundance of insects in different microhabitats of study site in Sirumalai hill. (i) To identify the composition of insects fauna at genus level (ii) To study the stream habitat types and (iii) To determine the diversity and distribution of insects in different microhabitats. The total of 9 taxa belonging to hemiptera (true bugs), coleopteran (beetles) and odonata (dragonflies) were collected in all the three sites. Hemipteran group contributed $62 \%$ to the total community, while the values coleoptera and odonata were 33 and $5 \%$. The mean abundance (number $/ \mathrm{m}^{2}$ ) per month was ranged between 18-24, 21-27 and 12-17 for hemiptera, coleoptera and odonata respectively. The Shannon's index values were 1.88, 1.88 and 1.92 for sandy, pool rocks and riffles, while the Simpson's index was $6.49,6.77$ and 6.73 . There were no significant difference in the relative abundance of insects between taxa and microinvertebrate of the stream indication that the evenness (95\%) of taxa at the sampling sites. The understanding of stream ecology a comprehensive approach integrating biotic and a biotic components of stream is essential, hence a preliminary report on biodiversity of aquatic insect community in Sirumalai hill stream was investigated.
\end{abstract}

Keywords: survey, diversity, distribution, stream insects, sirumalai hills, South India
Volume 2 Issue 6 - 2018

\author{
Ramar M,' Mahendran M, ${ }^{2}$ Kamalakannan S,' \\ Jayakumar E, ${ }^{2}$ Anbalagan ${ }^{3},{ }^{2}$ Murugan $\mathrm{K}^{1}$ \\ 'Department of Zoology, School of Life Sciences, Bharathiar \\ University, India \\ 2Department of Zoology, Vivekananda College, India \\ ${ }^{3}$ Department of Zoology, Loyola College, India
}

Correspondence: Ramar M, Department of Zoology, School of Life Sciences, Bharathiar University, Coimbatore - 64l 046, Tamil Nadu, India, Email ramarcri@gmail.com

Received: September 25, 2018 | Published: November 06, 2018

\section{Introduction}

Aquatic insects constitute over $95 \%$ of the total individual or species of macroinvertebrates in suitable fresh water biotopes. Scanning through the available literature on aquatic insects in India pertains to the distribution and abundance of mayflies. ${ }^{1,2}$ India is one of the world's twelve megadiversity countries. ${ }^{3}$ Insects contribute over half of all the recorded species and over three fourth of the estimated species, in the globe. ${ }^{4}$ However studies on other stream insects communities are fragmentary. ${ }^{5,6}$ Most streams of southern India have been substantially modified for irrigation and power generation, or they are impacted by pollutants including human sewage, run off from agriculture and industrial pollutants. Earlier studies on aquatic insects in southern India have focused primarily on the taxonomic monographs. A research lacuna of concern is the paucity of information on diversity and abundance of stream insects in the tropics. ${ }^{7}$ As aquatic insects are environmental indicators, the approaches to monitoring their occurrence, diversity and distribution are being favored manner Studies on the ecology of macroinvertebrates of some major streams in Southern Western Ghats have been well documented already. The species composition and distribution of Caddisflies in Southern Eastern that examined factors affecting large scale distribution. ${ }^{9}$ Only a few research on stream insects in sirumalai hills hence, we have selected in this study.

\section{Materials \& methods}

\section{Description of the study}

The study site, Sirumalai Hill is located in Dindigul district and extends upto Madurai district, Tamil Nadu (10² $\left.27^{\prime} \mathrm{N} 77^{\circ} 29^{\prime} \mathrm{E}\right)$, India. It is about $23 \mathrm{kms}$ away from Dindigul. The chosen stream is one among the several intermittent streams of the hill near a village called Ponnurki. Three randomly selected segments of the stream were marked as sampling sites. The distance between these three sites is approximately equal $(2 \mathrm{~km})$ and situated at an altitude 800 masl (metres average sea level). The stream averages $20 \mathrm{~m}$ wide. Maximum depth is $1.5 \mathrm{~m}$ which drops 0.5 to 0.7 in summer and the substrate was composed of a mixture of boulders rock, cobbles, pebbles, sand and silt in different microhabitats. A detailed account of the ecological profiles of this deciduous forest stream are reported by Nagendran. ${ }^{10}$

\section{Types of microhabitates}

Sandy: Bare sand or silt presents a relatively simple type of habitat. This site is a upstream ( $2 \mathrm{~km}$ from rocky type) width of $10 \mathrm{~m}$. This habitat exhibits more or less similar to the lenthic depositional condition, as there is a less water current.

Rocks: It is lotic, erosional and consists of boulders and rubble. Rocks encrusted with algae. The substratum is rubble and gravel integrated with coarse sand.

Riffles: The shallow microhabitat ( $10 \mathrm{~m}$ width) is located at $2 \mathrm{~km}$ down from rocky habitat. The substrate includes pebbles and cobbles. The loose stones of the stream have algal encrustation. The allocthnous leaf detritus form the principal source of food for aquatic insect nymphs. This site is shady due to the thick growth of trees such as Mangifera, Azadirachta and Citrus species.

Insect sampling: Insect samples were collected at every fortnight from 3 microhabitats during november 2002 to march 2003 with a kicknet $\left(1 \mathrm{~m}^{2}, 0.5\right.$ mesh size). For each sample a $1 \mathrm{~m}^{2}$ area as marked off in the habitat types of the Sirumalai stream. One person held the kicknet while the other person systematically sampled by disrupting the habitat vigorously for 5 minutes. The colleted insects were preserved in $70 \%$ alcohol and identified upto genus level by following Morse et al. ${ }^{11}$ and Sivaramakrishnan et al. ${ }^{12}$ Water samples were colleted in clean polythene bottles and transported immediately to the 
laboratory for analysis. Temperature (by a sensitive $0-50^{\circ} \mathrm{C}$ mercury thermometer) and (by using $\mathrm{P}^{\mathrm{H}}$ meter) were measured in the field. Dissolved oxygen content (fixed at the site itself) was measured by Azide modification of Winker's method ${ }^{13}$ in the laboratory.

\section{Statistical analysis}

I. Species richness represents the number of Taxa (species/month). It is calculated by

a. Margalef's Index $\left(\mathrm{R}_{1}\right)=\mathrm{S}-11 \mathrm{n}(\mathrm{n})$

Menhinick's Index $\left(\mathrm{R}_{2}\right)=\mathrm{s} \sqrt{\mathrm{n}}$

Where,

$\mathrm{S}=$ The total number of species in a community

$\mathrm{N}=$ Total number of Individuals observed.

II. For calculating the diversity index for various months, ShannonWeiner formula was used and

Simpson index is also used.

Shannon Weiner index $(\mathrm{H})=\sum$ pi $\ln (\mathrm{pi})$

Simpson Index $(\lambda)=\sum \mathrm{pi}^{2}$

Where,

$\mathrm{Pi}=$ is the proportion of " $\mathrm{i}$ "th species in the community

$\mathrm{S}=$ is the total number or species

$1 \mathrm{n}=$ is the log with base "e"
III. The various diversity indices and evenness were workout following Ludwig \& Reynolds. ${ }^{14}$

a. Pielou index $\left(\mathrm{E}_{1}\right)=\mathrm{H}^{1} \ln (\mathrm{S})$

b. Sheldon index $\left(\mathrm{E}_{2}\right)=\mathrm{e}^{\mathrm{H}} \mathrm{S}$

c. Heip index $\left(\mathrm{E}_{3}\right)=\mathrm{e}^{\mathrm{H}^{\prime}}-1 \mathrm{~S}-1$

Hill index $\left(\mathrm{E}_{4}\right)=1 \sqrt{\lambda} e^{H^{\prime}}$

Alantato index $\left(\mathrm{E}_{5}\right)=1 \sqrt{\lambda-1} e^{H^{\prime}}-1$

Where, $\mathrm{H}^{1}=$ Shannon-Weiner, $\mathrm{S}=$ Total number of species, ${ }^{\lambda=\text { Simpson }}$ index

Standard Deviation $(\mathrm{SD})=\sum \mathrm{d} 2 \sqrt{\mathrm{N}-1}$

Where, $d=$ deviation of each score from mean; $N=$ the total number of samples.

\section{Results and discussion}

\section{Microhabitats and physico-chemical features}

Table 1 lists the types of microhabitats of Sirumalai stream and the physico-chemical features of the study site. It includes the sandy area, pool rocks and riffles as microhabitats. Boulders and rubble (pool rocks) pebbles and cobbles (riffles) and sand, silt sediments (sandy) as substrate types. There were no significant changes in $\mathrm{P}^{\mathrm{H}}$, dissolved oxygen content and temperature. However, water current varied from $4 \mathrm{sec} / \mathrm{min}$ at pool rocks to $9 \mathrm{sec} / \mathrm{min}$ at riffles.

Table I Showing microhabitats, substrate types and physico chemical features of Sirumalai stream

\begin{tabular}{llllll} 
Microhabitat & Substrate type & Temperature $\left({ }^{\circ} \mathbf{C}\right)$ & PH & Dissolved oxygen $(\mathbf{m g} / \mathbf{l})$ & Water current $(\mathbf{s e c} / \mathbf{m})$ \\
\hline Sandy & Sand and silt sediment & $24.9 \pm I$ & 5.6 & 12 & 6 \\
Rocks & Bed rock & $23.1 \pm \mathrm{I}$ & 5.8 & 12.5 & 4 \\
Riffles & Small pebble & $23.2 \pm \mathrm{I}$ & 5.8 & 12.3 & 9 \\
\hline
\end{tabular}

Table 2 Species richness, abundance $\left(\right.$ Number $\left./ \mathrm{m}^{2}\right)$ and \% occurrence of aquatic insects in Sirumalai hill stream during November 2002 to March 2003

\begin{tabular}{llll}
\hline & Sandy & Rocks & Riffles \\
\hline Taxa & $\begin{array}{l}\text { Number } \\
\text { Occurrence }\end{array}$ & $\begin{array}{l}\text { Number } \\
\text { Occurrence }\end{array}$ & $\begin{array}{c}\text { Number } \\
\text { Occurrence }\end{array}$ \\
\hline Hemiptera: & & & \\
Hydrometraustralis sp. (Hydrometridae) & 169 & 159 & 149 \\
& 12.3 & 10.0 & 9.5 \\
Microvelia sp. (Vellidae) & 133 & 158 & 159 \\
& 9.7 & 10.0 & 10.2 \\
Rhyacobates sp. (Gerridae) & 182 & 248 & 202 \\
& 13.2 & 15.7 & 12.9 \\
Notonecta sp. (Notonectidae) & 107 & 112 & 135 \\
& 7.7 & 7.2 & 8.6 \\
Anisops sp. (Notonectidae) & 143 & 187 & 184 \\
& 10.4 & 11.8 & 11.8 \\
Ranatra sp. (Ranatridae) & 149 & 123 & 142 \\
Coleoptera: & 10.8 & 7.9 & 9.1 \\
Dineutus sp. (Gyrinidae) & & & \\
& 188 & 202 & 220 \\
Potamonecteus sp. (Dytiscidae) & 13.6 & 12.8 & 14.1 \\
Odanata: & 181 & 237 & 225 \\
Cephalaeschna sp. (Aeschnidae) & 13.2 & 15.1 & 14.4 \\
Total 9 & 1269.1 & 150 & 147 \\
\hline & 1378 & 9.5 & 9.4 \\
\hline & & 1576 & 1563 \\
\hline
\end{tabular}




\section{Insect composition}

Table 2 presents species richness, abundance and \% occurrence of aquatic insects. A total of 9 taxa belonging to 3 groups were collected from sandy, rocky and riffles of the stream. Nymphs of Hydrometraustralis sp. Microvelia sp, Rhyacobates sp, Notonecta $\mathrm{sp}$, Anispos sp and Ranatra sp of the group hemiptrea; Dinectus sp and potamonecteus sp belonging to coleptera and Cephalaeschana $\mathrm{sp}$ of odanata were the major insect communities represented in all the microhabitats throughout the study period. Among them, hemipteran group was contributing $62 \%$ to the total abundance in the community.

\section{Insect abundance}

Data on the mean abundance (Number of individuals $/ \mathrm{m}^{2}$ ) of insects as functions of month and habitat types and overall hemiptern insect abundance in rocky pool varied from $24 / \mathrm{m}^{2}$ in november to $28 / \mathrm{m}^{2}$ in march 2003. Similar trend was observed for coleptera; while the value for odanata ranged between $12-15 / \mathrm{m}^{2}$ throughout the study period. With reference to other habitats the same pattern was observed.

\section{Insect diversity}

Table 3 presents the values of richness, diversity and evenness indices workout for aquatic insects. The species richness was 9 taxa, ranged between 9-5 for the study period. Margale's index $\left(\mathrm{R}_{1}\right)$ and Menhinick's index $\left(\mathrm{R}_{2}\right)$ values were 1.21 and 0.57 in all the three microhabitats. The Shannon's index value ranged from 1.87 to 1.92 ; while the Simpson's index was 6.49 to 6.76. The Evenness index ( $\mathrm{E}_{1}$ to $\mathrm{E}_{5}$ ) ranged between 0.88 and 0.97 indicating the uniform distribution of insects in the community.

Table 3 Richness, diversity and evenness indices for aquatic insect insects in microhabitats

\begin{tabular}{llll}
\hline Index & Sandy & Rocks & Riffles \\
\hline Richness & & & \\
Species Richness $(\mathrm{S})$ & $9(9-6)$ & $9(9-6)$ & $9(9-5)$ \\
Margals index $\left(\mathrm{R}_{1}\right)$ & $\mathrm{I} .2 \mathrm{I}$ & $\mathrm{I} .18$ & $\mathrm{I} .2 \mathrm{I}$ \\
Menhinick's index $\left(\mathrm{R}_{2}\right)$ & 0.59 & 0.55 & 0.57 \\
Diversity & & & \\
Simpson's diversity $(\lambda)$ & 6.49 & 6.76 & 6.73 \\
Shannon's index $\left(\mathrm{H}_{1}\right)$ & $\mathrm{I} .87$ & $\mathrm{I} .88$ & 1.92 \\
Hills index $\left(\mathrm{N}_{1}\right)$ & 6.49 & 6.64 & 6.94 \\
Hills index $\left(\mathrm{N}_{2}\right)$ & 0.15 & 0.19 & 0.16 \\
Evenness & & & \\
Pielounin index $\left(\mathrm{E}_{1}\right)$ & 0.95 & 0.97 & 0.88 \\
Shildon index $\left(\mathrm{E}_{2}\right)$ & 0.93 & 0.95 & 0.97 \\
Heip index $\left(\mathrm{E}_{3}\right)$ & 0.92 & 0.94 & 0.97 \\
Hill index $\left(\mathrm{E}_{4}\right)$ & 0.04 & 0.11 & 0.02 \\
Alantato index $\left(\mathrm{E}_{5}\right)$ & 0.14 & 0.15 & 0.15 \\
\hline
\end{tabular}

Aquatic insects live some portion of their life in the water in that present study 9 taxa belonging to 3 principal orders are identified. Hemiptera and coleoptera are the important orders prevalent in this stream. The Sirumalai hill stream with 6 larval species of hemipteran, two species of coleoptera are reported in the present investigation with reference to hemiptera considerable information on both western and eastern ghates are available. For instance, two families from Silent valley two families in Alagar hill ${ }^{15}$ and twelve families in Javadi hill ${ }^{16}$ and three families from various streams of south western Indian. ${ }^{17}$ Data on coleoptera is very much limited and reported as one family in Alagar hill. ${ }^{15} 10$ sps of ephemeroptera in Courtallam streams ${ }^{1}$ streams of Western ghats ${ }^{18}$ and in the stream of silent valley Kuntipuzha Burton \& Sivaramakrishnan ${ }^{5}$ found 5 species of ephemeroptera compared to 29 species for Hong Hong streams in and or 17sps of northern eastern India. ${ }^{2}$ Geographically,backflies are worldwide in distribution except some areas of the tropics like Zew Zealand, Hawaii and some minor island groups. ${ }^{19}$ The diversity indices indicate that this stream has a well balanced insect community that enjoys an even representation of several species indicating the dynamic nature of this aquatic ecosystem.

While the abundance, density and biomass of aquatic insects are evaluate according to different seasonal and spatial levels, it appear that these parameters did not vary in the stations except in stream where all parameters were higher during the rainy season. As mentioned in previous studies, the little variations in abundance, density and biomass observed in both rainy and dry seasons could be related to the low seasonal variation of environmental conditions in the four stations. ${ }^{20,21}$ The conservation community has recently had heated debates on the various conceptual and practical values of indicator, umbrella, flagship, and keystone species ${ }^{22-24}$ when it comes to the assessment and preservation of biodiversity. In the Hawaiian Islands there has also been some degree of controversy, with inappropriate attempts to use Index of Biotic Integrity (IBI), developed for continental salmonid streams, to rank and assess Hawaiian streams..$^{25}$

In the chosen stream hemiptera and coleoptera are both common abundant throughout the period likely due to habitat generalits. ${ }^{26}$ Invertebrate abundance and percentage composition of shredders, grazers and predators were higher in small than in large rivers. This result likely occurred because nutrients, autochthonous and allochonous inputs and canopy coverage were high in small streams, which provide food and predation protection resources for the invertebrates. ${ }^{27,28}$ Rebora et al..$^{29}$ studied the lateral protrusions of the head of the stonefly larva Leuctra cf.signifera. Jacobsen et al..$^{30}$ indicated differences in the number of families and general diversity in tropical as compared to temperate zones, with higher richness and diversity in the tropics than in the temperate zones.

\section{Conclusion}

A survey was conducted to investigate the faunal diversity of insects from Sirumalai hill stream. There were no significant difference in the relative abundance of insects between taxa and microinvertebrate of the stream indication that the evenness $(95 \%)$ of taxa at the sampling sites. The Sirumalai stream exhibited few taxa (species/site) and low diversity the probable reasons is heterogeneity of habitats, substrate types and land-use changes are implicated. Other than aquatic or semiaquatic species such as Collembola (springtails), Ephemeroptera (mayflies), Plecoptera (stoneflies), Megaloptera (fishflies), Neuroptera (lacewings), Heteroptera (waterbus), Hymenoptera (polyhrachis sokolova), Diptera (mosquitoes), Mecoptera (scorpionflies), Lepidoptera (moths), Trichoptera (caddisflies) were not found in this stream that particular period.

\section{Acknowledgements}

As well we wish to thank all staff for their technical assistance. Assistance rendered by all the participants for their cooperation is gratefully acknowledged. 


\section{Conflict of interest}

Authors declare that there is no conflict of interest.

\section{References}

1. Sivaramakrishnan KG, Job SV. Studies on mayfly populations of courtallam streams. Proc Symp Ecol Anim Popul Zool Surv India. 1981;2:105-116.

2. Gupta A, Michael RG. Diversity, distribution and seasonal abundance of Ephemreoptera in streams of Megahalaya state, India. Hydrobiologia. 1992;228(2):131-139.

3. Gadgil M. Deploying student power to monitor India's lifescape. Curr Sci. 1996;71:688-697.

4. Hammond PM. Species inventory in global diversity: Status of the Earth' living resources. In: Groombridge B, editor. Chapman and Hall; 1992. p: 17-39.

5. Burton TM, Sivaramakrishnan KG. Composition of the insect community in the streams of the silent valley national park in south India. Tropical Ecology. 1993;34(1):1-16.

6. Smija MS, Nagendran AN. Genetic diversity of aquatic insects in three hill streams of western ghats, south India. In: Aravind kumar, editors. Environment and its challengers. Ashis publishing house, New Delhi; 2002.

7. Gastron KJ, Williams PH. Spatial patterns in taxonomic diversity. In: Gaston KJ, editors. Biodiversity and biology of numbers and differences. Blackwell Science; 1996. p. 202-229.

8. Anbalagan S, Dinakaran S. Seasonal variation of Diversity and Habitat Preferences of aquatic insects along the longitudinal gradient of Ghandan River Basin South- West Ghats (India). Acta Zoological Bulgarica. 2006;58(2):253-264.

9. Dinakaran S, Anbalagan S. Anthropogenic impacts on Aquatic insects in six streams of South Western Ghats. J Insect Science. 2007;7(37):9.

10. Nagendran NA. An Illustrated ecology of Sirumalai hill stream. Society for environmental Research and value education, Madurai; 2001. p. 1-10.

11. Morse JC, Yang L, Tian L. Aquatic insects of China useful for monitoring water quality, Hohai University press, Nanjing; 1994. p. 570.

12. Sivaramakrishnan KG, Madhyasthan NA, Subramanian KA. Field guide to Aquatic macrinvertebrates. Cent Ecol Sci Indian Inst Sci, Bangalore; 1998. p. 58 .

13. APHA. Standard methods for the estimation of water and waste water. 5th ed, New York (American Public Health Association); 1980.

14. Ludwig JA, Reynolds JF. Statistical Ecology. A Wiley -Inter science publications. John wiley and sons, New York; 1988. p. 337.

15. Dinakaran S, Krishnan N. Study on diversity of aquatic insects in a tropical stream of Alagar hills (Eastern Ghats). Proc Bio-divresity; 1997. p. 111-112.

16. Thirumalai G. Aquatic and semi-aquatic hemipterns (Insecta) of Javadi hills, Tamilnadu. Zool Surv India Occasion; 1989. p. 118:55.

17. Sivaramakrishnan KG, Venkataraman K, Moorthy RV, et al. Aquatic insect diversity and ubiquity of the streams of the western ghats. Indian Ins Sci. 2002;80:537-552.

18. Nagendran NA, Smija MS. A seminal report on diversity of higher taxa of aquatic insects in three hills streams of western ghats, south India. J Curr Sci. 2002;2:227-232.

19. Taylor MA, Coop RL,Wall RL. Veterinary parasitology. 3rd ed. Blackwell publishing; 2007.

20. Florencio M, Serrano L, Gomez-Rodriguez C, et al. Inter- and intraannual variations of macroinvertebrate assemblages are related to the hydroperiod in Mediterranean temporary ponds. Hydrobiologia. 2009;634(1):167-183.

21. Jana S, Pahari PR, Dutta TK, et al. Diversity and community structure of aquatic insects in a pond in Midnapore town, West Bengal, India. Journal of Environmental Biology. 2009;30(2):283-287.

22. Simberloff D. Flagships, umbrellas, and keystones: is single-species management passé in the landscape era?. Biological Conservation. 1998;83(3):247-257.

23. Andelman SJ, Fagan WF. Umbrellas and flagships: efficient conservation surrogates or expensive mistakes? Proceedings of the National Academy of Sciences. 2000;97(11):5954-5959.

24. Rubinoff D. Evaluating the California Gnatcatcher as an Umbrella Species for Conservation of Southern California Coastal Sage Scrub. Conservation Biology. 2001;15(5):1374-1383.

25. Parham JE. Survey techniques for freshwater streams on oceanic islands: important design considerations for the PABITRA Project. Pacific Science. 2005;59(2):283-291.

26. Merritt RW, Cummins KW. An introduction to aquatic insects of north America. 2nd ed, Kenda /Hunt publishing co. Iowa; 1984.

27. Mundie JH, Simpson KS, Perrin CJ. Responses of stream periphyton and benthic insects to increases in dissolved Inorganic phosphorous in a mescosm. Can J Fish aquat Sci. 1991;48(11):2061-2072.

28. Sweeney BW. Effects of streamside vegetation on macroinvertebrate communities of white clay creek in eastern north America. Proc Acad Nat Sci Philadelpia. 1993;144:291-340.

29. Rebora M, Muranyi D, Piersanti S, et al. The lateral protrusions of the head of the stonefly larva Leuctra cf.signifera (Plecoptera: Leuctridae). Aquatic Insects. 2010;32(4):259-264.

30. Jacobsen D. Contrasting patterns in local and zonal family richness of stream invertebrates along an Andean altitudinal gradient. Freshwater Biol. 2004;49:1293-1305. 